\title{
A Polymerase Chain Reaction Protocol for the Detection of Clavibacter xyli subsp. xyli, the Causal Bacterium of Sugarcane Ratoon Stunting Disease
}

Y.-B. Pan, M. P. Grisham, and D. M. Burner, USDA-ARS, Southern Regional Research Center, Sugarcane Research Unit, P.O. Box 470, Houma, LA 70361; K. E. Damann, Jr., Department of Plant Pathology and Crop Physiology, Agricultural Center, Louisiana State University, Baton Rouge 70803; and Q. Wei, USDA-ARS, Southern Regional Research Center, Sugarcane Research Unit, P.O. Box 470, Houma, LA 70361

\begin{abstract}
Pan, Y.-B., Grisham, M. P., Burner, D. M., Damann, K. E., Jr., and Wei, Q. 1998. A polymerase chain reaction protocol for the detection of Clavibacter xyli subsp. xyli, the causal bacterium of sugarcane ratoon stunting disease. 82:285-290.

A polymerase chain reaction (PCR) protocol was developed that specifically detected Clavibacter xyli subsp. xyli, the causal agent of sugarcane ratoon stunting disease. Generic PCR products from the intergenic transcribed spacer (ITS) region of 16S-23S ribosomal DNA of $C$. xyli subsp. xyli and C. xyli subsp. cynodontis were cloned and sequenced. Based on a multiple sequence alignment among these two sequences and other nonredundant highly homologous sequences from the database, two $C$. xyli subsp. xyli-specific PCR primers were designed, Cxx1 (5' CCGAAGTGAGCAGATTGACC) and Cxx2 (5' ACCCTGTGTTGTTTTCAACG). These two 20-mer oligonucleotides primed the specific amplification of a 438-bp DNA product from genomic DNA samples of $21 C$. xyli subsp. xyli strains. Amplification was not observed with genomic DNA of one C. xyli subsp. cynodontis strain, five strains of four other Clavibacter species, and two strains of two Rathayibacter species. The 438-bp PCR product also was amplified directly from cultured $C$. xyli subsp. xyli cells and from $C$. xyli subsp. $x y l i$-infected sugarcane vascular sap with a unique reaction buffer containing polyvinylpyrrolidone and ficoll. Extraction of genomic DNA was not necessary prior to PCR assay.
\end{abstract}

Ratoon stunting disease (RSD) of sugarcane (Saccharum interspecific hybrids) is caused by Clavibacter xyli subsp. xyli, a small, fastidious, gram-positive, xylemlimited coryneform bacterium $(12,13,22,38)$. The disease occurs in all sugarcane production areas of the world and can cause up to $50 \%$ yield loss in susceptible cultivars under drought conditions (6). Diagnosis of RSD is difficult because $C$. $x y l i$ subsp. $x y l i$-infected plants show no external symptoms. Yield loss of infected plants is due to reduced vigor and tillering, especially in ratoon crops. Internal symptoms, including a salmon pink discoloration just below the growing point of young cane and an orange-red discoloration of the nodal

Corresponding author: Y.-B. Pan

E-mail: ypan@nola.srrc.usda.gov

Product names and trademarks are mentioned to report factually on available data; however, the USDA neither guarantees nor warrants the standard of the product, and the use of the name by USDA does not imply the approval of the product to the exclusion of others that may also be suitable.

Accepted for publication 16 December 1997.

Publication no. D-1998-0116-02R

This article is in the public domain and not copyrightable. It may be freely reprinted with customary crediting of the source. The American Phytopathological Society, 1998. vascular bundles in mature cane stalks, are unreliable because these symptoms vary within and among cultivars. Isolation of the bacterium is difficult due to its fastidious nature and the lack of an optimized medium. Microscopic and immunological procedures $(12,20,23,24,39)$ are effective in detecting $C$. xyli subsp. xyli later in the growing season when the bacterium is at a high titer; however, detection can be unreliable with these methods in early to midseason, when a management decision must be made about which stalks are to be used as the seed cane for the next crop cycle. Immunological methods also are limited by the availability of anti-C. xyli subsp. xyli antibodies.

Recently, various DNA probes have been developed to identify and detect microorganisms $(19,25)$. For example, DNA probes derived from the ribosomal intergenic transcribed spacer (ITS) region of $16 \mathrm{~S}-23 \mathrm{~S}$ ribosomal DNA proved useful in the identification of eubacteria (5), and plasmid-borne DNA probes detected Clavibacter michiganensis subsp. sepedonicus in field-grown potatoes $(16,35,37)$. PCR protocols were developed to detect Xanthomonas albilineans, another xylemlimited bacterial pathogen causing the sugarcane leaf scald disease $(26,34)$. DNAbased diagnostic tools for $C$. xyli subsp. $x y l i$ detection that used either $C$. xyli subsp. $x y l i$-specific DNA probes from unknown genomic region (7) or C. xyli subsp. xyli- specific PCR primers within the 16S-23S ribosomal DNA $(3,17)$ have been reported; however, none of these reports provided DNA sequence information. In a recent study, a 566-bp L1/G1-primed DNA product from the ITS region of the 16S-23S ribosomal DNA of $C$. xyli subsp. xyli was found to be $C$. xyli-specific and was used as a DNA probe to detect $C$. xyli subsp. xyli in tissue blot hybridizations (unpublished). The objective of this study was to develop specific primers and a PCR protocol for the detection and identification of $C$. xyli subsp. xyli.

\section{MATERIALS AND METHODS}

Bacterial strains. Two local $C$. $x y l i$ subsp. xyli strains, 16296 and CP53-1, and a collection of $19 C$. xyli subsp. xyli strains isolated from sugarcane grown in different geographic areas (provided by S. M. Brumbly, Bureau of Sugar Experiment Stations, Australia) were included in the study. The collection included $C$. xyli subsp. xyli strains UQ2271 (isolated in Australia), UQ2272 (United States), QPF83S (Australia), QPF110A (Australia), QPF110B (Australia), QPF115 (Australia), QPF122 (Australia), QPF124 (Australia), QPF130 (Australia), QPF138 (Australia), QPF153 (Australia), QPFUNK (Australia), BBERGROY1 (Australia), BIB (Brazil), B2NA56-79 (Brazil), B3SP70-3370 (Brazil), L1A (United States), J1 (Japan), and S1A (South Africa). Genomic DNA samples of Clavibacter michiganensis subsp. michiganensis, C. michiganensis subsp. sepedonicus, C. michiganensis subsp. insidiosus, C. michiganensis subsp. nebraskensis, Rathayibacter iranicus, and $R$. tritici were provided by X. Li (Terragen, Vancouver, Canada). $X$. albilineans, seven unidentified sugarcane saprophytic bacterial isolates (34), and a genomic DNA sample of strain $C x c 7$ of $C$. xyli subsp. cynodontis, the causal agent of Bermudagrass stunting disease $(13,14)$, from Mary Metzler (33) were also included in the study.

Amplification, cloning, and sequencing of PCR products. PCR reaction mix, thermal cycling program, agarose gel electrophoresis, radioactive labeling of probe, Southern hybridization, and gel purification of PCR products were according to Pan et al. (34). L1/G1-primed PCR products from the local $C$. xyli subsp. xyli strain 
16296 and the C. xyli subsp. cynodontis strain $C x c 7$ were gel purified and cloned into pCR2.1 vector using an Original TA Cloning Kit (Invitrogen Corporation, Carlsbad, CA) following the manufacturer's recommendations. Recombinant clones were selected by colony hybridization. Plasmid DNAs were extracted from 3-ml overnight TOP10F' cultures by the alkali lysis method (36), and DNA con- centrations were determined on GeneQuant II spectrophotometer (Pharmacia Biotech, Piscataway, NJ). Six recombinant plasmid clones per construct were sequenced on an automatic DNA Sequencer ABI200, Model 377 (Applied Biosystems, Foster City, CA) at the DNA Sequencing Facility, Iowa State University, Ames.

Computer-assisted DNA sequence analysis and primer design. Individual
DNA sequences were visually checked and edited against corresponding electropherograms to obtain the final nucleotide sequences, 566 bp for $C$. xyli subsp. xyli and 546 bp for $C$. xyli subsp. cynodontis. The 566-bp sequence was used to search for its nonredundant, highly homologous sequences in GenBank+EMBL+DDBJ+PDB database using the BLASTN program of NCBI (2). A total of four GenBank se-

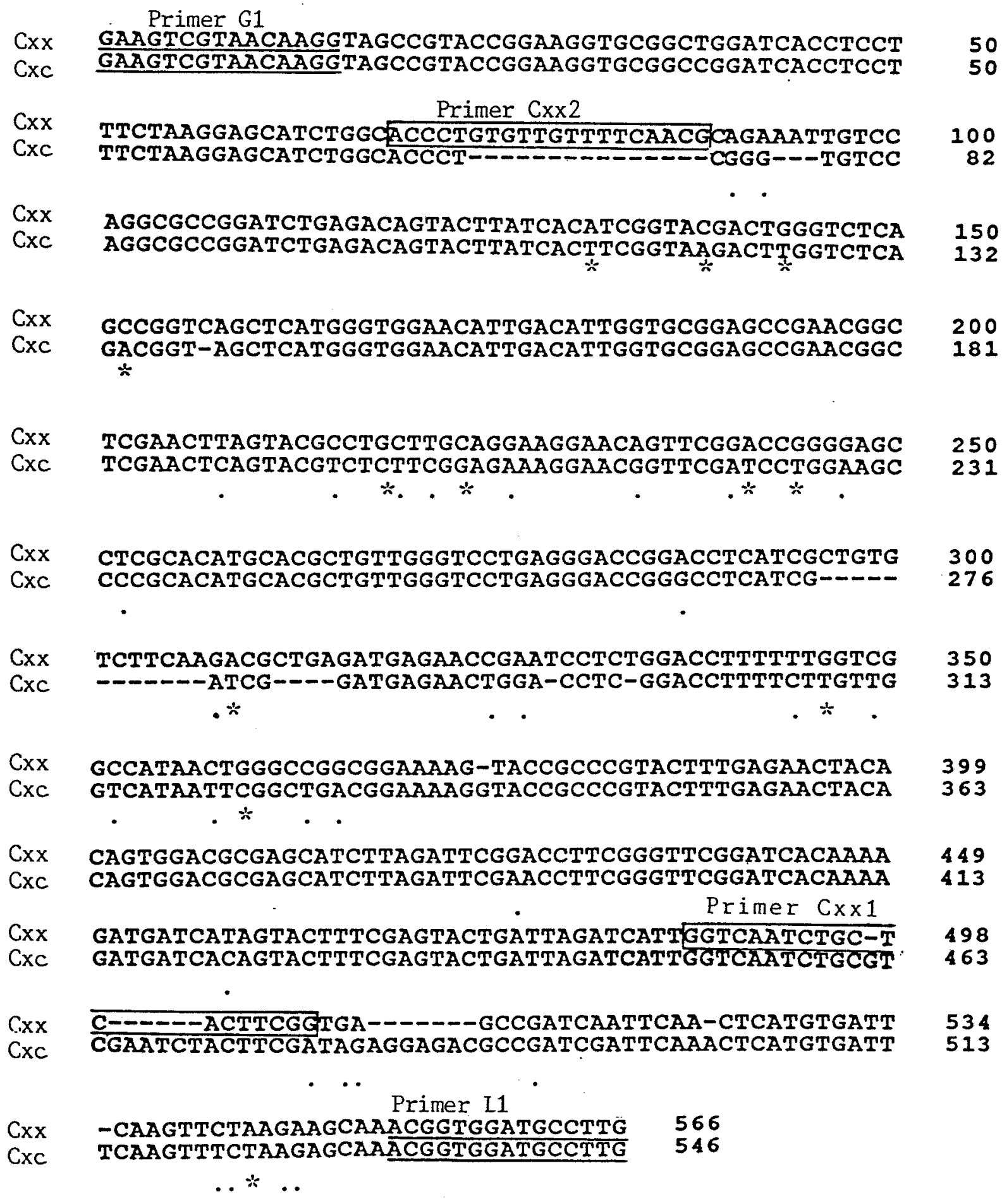

Fig. 1. Aligned nucleotide sequences of the L1/G1-primed polymerase chain reaction (PCR) amplification products from the intergenic transcribed spacer region of 16S-23S ribosomal DNA of Clavibacter xyli subsp. xyli (Cxx) and C. xyli subsp. cynodontis (Cxc). The sequence of primer G1 (27) and the inverted complimentary sequence of primer L1 (27) are underlined. The sequence of primer Cxx2 and the inverted complimentary sequence of primer Cxx1 are boxed. Base transitions are indicated by a dot underneath the bases, and base transversions are indicated by an asterisk. 
quences representing four subspecies of $C$. michiganensis (GenBank Accession No. U09378, U09379 or U09380, U09381, and U09382) (29) and the two C. xyli subspecies sequences from this study were aligned using the PC/GENE Program (IntelliGenetics, Mountain View, CA). PCR primers Cxx1 and Cxx2 were designed with the Primer Detective software program (CLONTECH Laboratories, Palo Alto, CA).

Specificity and sensitivity of PCR protocol. Genomic DNA samples from all the bacterial species listed were tested for the specificity of primers $\mathrm{Cxx} 1$ and $\mathrm{Cxx} 2$. PCR reactions were assembled on ice and started in a preheated $\left(95^{\circ} \mathrm{C}\right)$ PTC- 100 Programmable Thermal Controller (Model 60, MJ Research, Watertown, MA) with a PCR program of $95^{\circ} \mathrm{C}$ for $5 \mathrm{~min}, 40$ cycles of $95^{\circ} \mathrm{C}$ for $1 \mathrm{~s}, 57^{\circ} \mathrm{C}$ for $1 \mathrm{~s}$, and $72^{\circ} \mathrm{C}$ for $30 \mathrm{~s}$, and final extension at $72^{\circ} \mathrm{C}$ for $5 \mathrm{~min}$. Each $25-\mu \mathrm{l}$ volume reaction mixture contained $50 \mathrm{mM} \mathrm{KCl}, 2 \mathrm{mM} \mathrm{MgCl} 2,10 \mathrm{mM}$ Tris- $\mathrm{HCl}$ ( $\mathrm{pH} 8.3$ ), $0.2 \mathrm{mM}$ each of dATP, dTTP, dGTP, and dCTP, $0.4 \mu \mathrm{M}$ each primer, 0.625 units of Taq DNA polymerase (Promega Corp., Madison, WI), and $1 \mu \mathrm{l}$ of sample. For sensitivity tests, the concentration of a genomic DNA sample from the local $C$. xyli subsp. xyli strain 16296 was determined on a DyNA Quant 200 Fluorometer (Hoefer Pharmacia Biotech, San Francisco, CA). Tenfold serial dilutions of this DNA sample were prepared in sterile water. A range between 10 fg and 10 ng was tested by PCR.

Detection of $C$. xyli subsp. xyli in sugarcane vascular sap. The efficacy of the PCR protocol to detect C. xyli subsp. xyli in sugarcane vascular sap was compared with the tissue blot immunobinding assay (TB-IBA) (24). Both a tissue and a vascular sap sample were collected from the basal internode of each of 120 sugarcane stalks. The stalks were from plants in a nursery grown from cane that was either inoculated with $C$. xyli subsp. xyli (60 stalks) or hot-water treated (60 stalks). The tissue samples for TB-IBA were prepared according to the methods of Harrison and Davis (24), and the sap samples were extracted by positive pressure. Following extraction, the sap samples were stored at $-20^{\circ} \mathrm{C}$ for 2 months. Sap samples were thawed at $37^{\circ} \mathrm{C}$ and vortexed to resuspend. A $500-\mu l$ aliquot of each sap sample was transferred to a new microfuge tube and spun at $13,450 \times g$. The supernatant was decanted, and the pellet was resuspended in the remaining supernatant by vortexing immediately before a $1-\mu \mathrm{l}$ aliquot was taken for PCR assay using the same reaction mixture, except that $0.8 \%$ (wt/vol) polyvinylpyrrolidone (MW $=360,000)$ and $0.8 \%$ (wt/vol) ficoll $(\mathrm{MW}=400,000)$ also were included.

\section{RESULTS}

DNA sequence of the L1/G1-primed PCR products from $C$. xyli subsp. xyli and $C$. xyli subsp. cynodontis. The nucleotide sequence of one strand of the L1/G1-primed PCR products from $C$. $x y l i$ subsp. $x y l i$ and the sequence from $C$. xyli subsp. cynodontis are shown in Figure 1. The total number of bases for the product from C. xyli subsp. xyli is 566, of which 134 are adenosine, 139 cytosine, 158 guanosine, and 135 thymine, with a GC content of $52.5 \%$. The total number of bases for the product from $C$. xyli subsp. cynodontis is 546, of which 132 are adenosine, 132 cytosine, 152 guanosine, and 130 thymine, with a GC content of $52 \%$. Alignment of the two sequences revealed the following sequence variations: (i) 31 transitions and 12 transversions; (ii) three 1-base, one 3-base, one 4-base, one 12base, and one 15-base deletion in C. xyli subsp. cynodontis-derived PCR product; and (iii) four 1-base, one 6-base, and one 7-base deletion in C. xyli subsp. xyli-derived PCR product (Fig. 1). Overall, the two sequences shared $89.9 \%$ sequence identity.

Selection of $C$. xyli subsp. xyli-specific PCR primers. From the 566-bp C. xyli subsp. xyli sequence, Primer Detective software program identified nine 20-mer

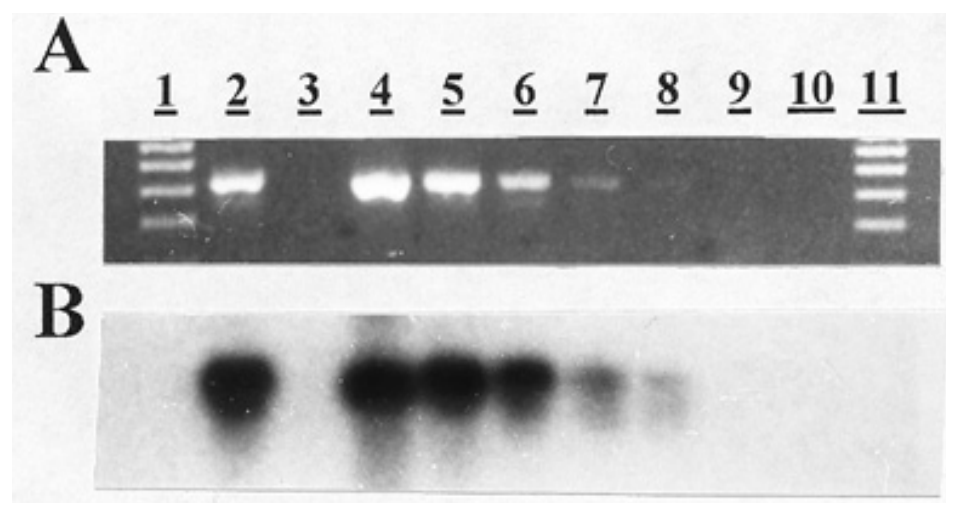

Fig. 3. (A) Ethidium bromide-stained polymerase chain reaction (PCR) products following amplification with primers $\mathrm{Cxx} 1$ and $\mathrm{Cxx} 2$ from 10-fold dilution series of Clavibacter xyli subsp. xyli genomic DNA. Lane designation: 1 and 11, 100-bp size markers $(600,500,400$, and $300 \mathrm{bp}$, respectively) (MBI Fermentas, Amherst, NY); 2, positive control using $C$. xyli subsp. xyli cells; 3, negative control using sterile water; 4, $10 \mathrm{ng}$ of DNA template; $5,1 \mathrm{ng} ; 6,100 \mathrm{pg} ; 7,10 \mathrm{pg} ; 8,1 \mathrm{pg} ; 9,100 \mathrm{fg}$; $10,10 \mathrm{fg}$. (B) Autoradiograph of Southern blot of gel in panel A probed with a $566-\mathrm{bp}{ }^{32} \mathrm{P}$-labeled L1/G1-primed PCR product from $C$. xyli subsp. $x y l i$ genomic DNA.

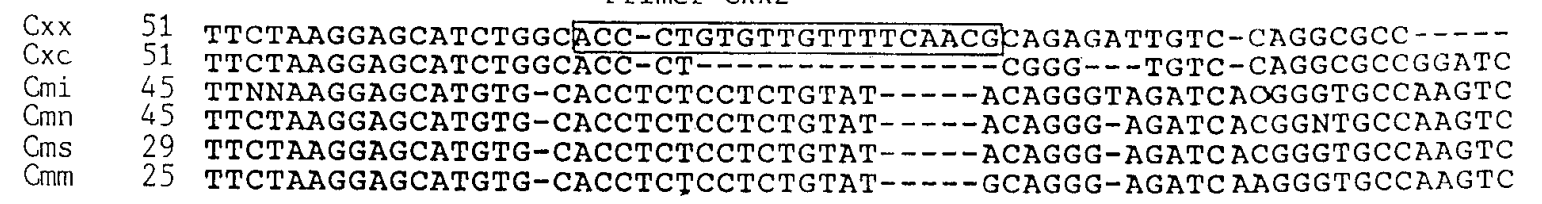

$\begin{array}{ll}\text { Cxx } & 481 \\ \text { Cxc } & 445 \\ \text { Cmi } & 42 \\ \text { Cmn } & 41 \\ \text { Cms } & 40 \\ \text { Cmm } & 398\end{array}$

Primer Cxx1

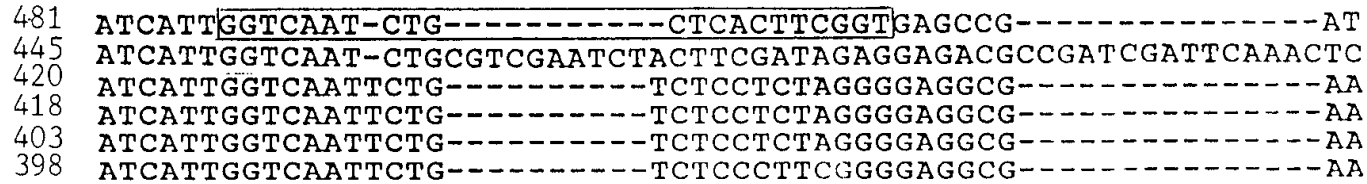

Fig. 2. Aligned nucleotide sequences among Clavibacter xyli subsp. xyli (Cxx), C. xyli subsp. cynodontis (Cxc), C. michiganensis subsp. insidiosus (Cmi) (GenBank Accession No. U09378), C. michiganensis subsp. nebraskensis (Cmn) (GenBank Accession No. U09381), C. michiganensis subsp. sepedonicus (Cms) (GenBank Accession No. U09382), and C. michiganensis subsp. michiganensis (Cmm) (GenBank No. U09379 and U09380) around the regions of primers Cxx1 and Cxx2. The inverted complimentary sequence of Cxx1 and the sequence of Cxx2 are in the boxes. Base position numbers shown on the left begin with primer G1 for C. xyli subsp. xyli and C. xyli subsp. cynodontis, others were defined by Li and De Boer (29). 
primers toward the G1 primer end (data not shown) and one reverse 20-mer primer toward the L1 primer end (Figs. 1 and 2, position 487 to 506 in $C$. xyli subsp. xyli strand) for consideration. Upon multiple sequence alignment, the sequences of six of the nine primers toward the G1 end were highly homologous to those of the four subspecies of $C$. michiganensis included in this study (data not shown). Of the remaining three primers (69 to 88,81 to 100 , and 84 to 103 ), the one from base 69 to base 88 was selected because it spanned the most variable spacer region among these bacterial species (Fig. 2). In this region, a 5-base deletion and an additional thymine were found from the four subspecies of the C. michiganensis. Also in this region, there was a 15-base deletion in C. xyli subsp. cynodontis. In addition, other forms of sequence variation existed among these bacterial species. This primer was designated as $\mathrm{Cxx} 2$ with a sequence of $5^{\prime}$

Table 1. Detection of Clavibacter xyli subsp. $x y l i$ by polymerase chain reaction (PCR) and tissue blot immunobinding assay (TB-IBA)

\begin{tabular}{ccc}
\hline Samples & PCR $^{\mathbf{a}}$ & TB-IBA $^{\mathbf{b}}$ \\
\hline 34 & + & + \\
7 & - & + \\
3 & + & - \\
76 & - & - \\
Subtotal 120 & & \\
Total positive & 37 & 41 \\
\hline
\end{tabular}

a Sap samples used for PCR were collected from the same stalks from which tissue blots were prepared. $+=C$. xyli subsp. xyli detected, $-=$ not detected.

${ }^{b}$ Anti-C. $x y l i$ subsp. xyli polyclonal antibodies were used as the primary antibody (Cocalico Biologicals, Reamstown, PA 17567).
ACC CTG TGT TGT TTT CAA CG. The other reverse primer toward the L1 primer end (487 to 506) was designated as Cxx1 with a sequence of $5^{\prime}$ CCG AAG TGA GCA GAT TGA CC.

Specificity of the Cxx1 and Cxx2 primers. As expected, primers $\mathrm{Cxx} 1$ and Cxx2 primed the amplification of a 438-bp DNA product from genomic DNA samples of all the 21 C. xyli subsp. xyli strains. No amplification product was observed from genomic DNA samples of $C$. xyli subsp. cynodontis, C. michiganensis subsp. michiganensis, C. michiganensis subsp. nebraskensis, C. michiganensis subsp. sepedonicus, C. michiganensis subsp. insidiosus, $R$. iranicus, $R$. tritici, $X$. albilineans, or saprophytic bacteria from sugarcane. In parallel control PCR experiments using universal primers L1 and G1, all the DNA samples produced a PCR product (data not shown).

Sensitivity of the PCR protocol. Using the PCR protocol, the 438-bp PCR product was observable in agarose gels with ethidium bromide staining $(0.5 \mu \mathrm{g} / \mathrm{ml})$ from PCR reactions in which as little as $1 \mathrm{pg}$ of C. xyli subsp. xyli genomic DNA template was present (Fig. 3A). The detection limit was not improved by Southern blot hybridization with a ${ }^{32} \mathrm{P}$-labeled 566-bp L1/G1-primed PCR probe (Fig. 3B).

Detection of $C$. xyli subsp. xyli in sugarcane vascular sap. Primers $\mathrm{Cxx} 1$ and Cxx2 primed the amplification of the 438bp DNA product directly from cultured $C$. xyli subsp. xyli cells and from 37 of 60 vascular sap samples from stalks grown from $C$. xyli subsp. xyli-infected stalks using the PVP- and ficoll-containing PCR reaction mixture (Table 1 , examples are shown in Fig. 4). In the comparison of the
PCR protocol with TB-IBA, 34 samples tested positive both by PCR and by TBIBA, three tested positive by PCR but not by TB-IBA, and seven tested positive by TB-IBA but not by PCR. The RSD bacterium was not detected by either method in 76 samples, including all of the 60 sap samples from stalks of plants grown from hot-water treated stalks.

\section{DISCUSSION}

Specific primers and a PCR protocol were developed for the detection of $C$. xyli subsp. xyli. Current diagnostic methods for C. xyli subsp. xyli $(4,8-11,21,28,39)$ are effective late in the growing season when titers of the bacterium are high. In general, the detection limit is $10^{6} \mathrm{CFU} / \mathrm{ml}$ by enzyme immunoassay (9), $10^{4-5}$ by the fluorescent-antibody-direct-count-on-filters technique (11), and $10^{6}$ by TB-IBA (24). In a related study, about $10^{5} \mathrm{CFU}$ of $X$. albilineans per $\mathrm{ml}$ was detected by TB-IBA in $50 \%$ of the assays (8). The detection limit for $C$. xyli subsp. xyli by our PCR protocol was $1 \mathrm{pg}$ of genomic DNA, either by ethidium bromide staining or by Southern blot hybridization. This was comparable to our PCR protocol for X. albilineans (34). Due to the difficulty in titrating $C$. $x y l i$ subsp. xyli cells because of the bacterium's fastidious nature, sensitivity tests on cells were not successful.

PCR-based detection methods for Clavibacter species using primers derived from plasmid-borne genes or genomic DNA have been reported in recent years $(3,15,17,18,29,30,35)$. Dreier et al. (15) developed a PCR procedure using primers originated from a plasmid-borne gene pat1 sequence to detect virulent C. michi-

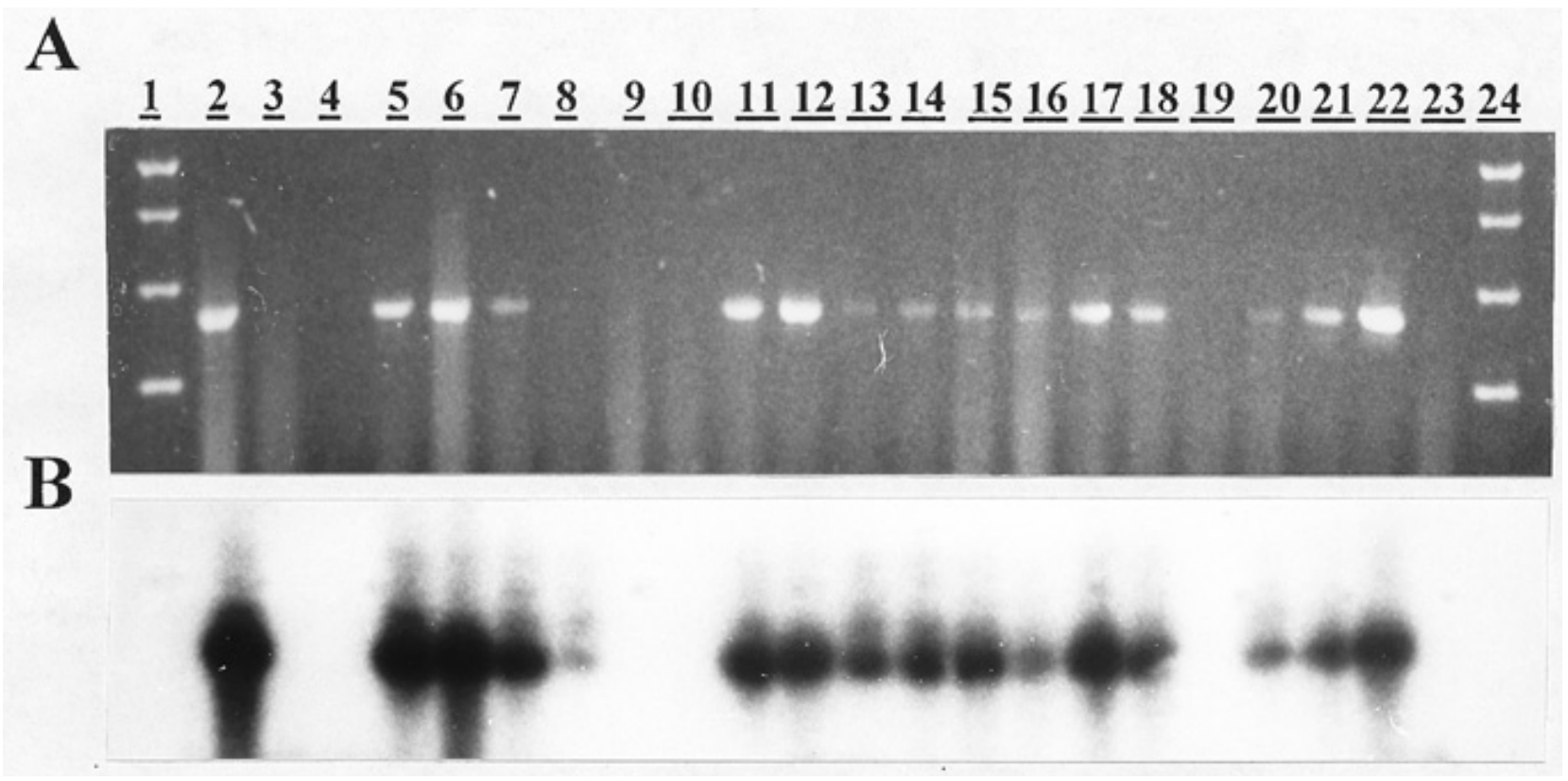

Fig. 4. (A) Ethidium bromide-stained polymerase chain reaction (PCR) products following amplification with primers Cxx1 and Cxx2 from sugarcane vascular sap samples (lanes 4 to 23), from cultured Clavibacter xyli subsp. xyli cells (lane 2), and from sterile water (lane 3). DNA size markers (lanes 1 and 24) are 1,000, 750, 500, and 300 bp, respectively. (B) Autoradiograph of Southern blot of gel in panel A probed with a 566-bp ${ }^{32} \mathrm{P}-1 \mathrm{abeled}$ L1/G1primed PCR product from C. xyli subsp. xyli genomic DNA. 
ganensis subsp. michiganensis strains in infected tomato tissue. Firrao and Locci (18) employed PCR to identify C. michiganensis subsp. sepedonicus. $\mathrm{Li}$ and $\mathrm{De}$ Boer (29) sequenced the 16S-23S ribosomal DNA regions of five subspecies of Clavibacter and designed a pair of primers within the ITS region that were highly specific to the subspecies $C$. michiganensis subsp. sepedonicus. PCR protocols for the detection of $C$. xyli subsp. xyli have been reported by Lopes and Damann (30), Astua-Monge et al. (3), and Fegan et al. (17); all used primers derived from the ITS region of $16 \mathrm{~S}-23 \mathrm{~S}$ ribosomal DNA. However, Lopes and Damann (30) only used the universal primers L1 and G1, which also prime amplification products from other bacterial species (27). No primer sequence information was reported by Astua-Monge et al. (3) and Fegan et al. (17). While the L1/G1-derived 566-bp DNA probe was specific at the species level, it did not differentiate the two subspecies $C$. xyli subsp. xyli and $C$. xyli subsp. cynodontis. In contrast, the PCR protocol developed in this study was highly specific to $C$. xyli subsp. xyli because primers $\mathrm{Cxx} 1$ and $\mathrm{Cxx} 2$ were selected from the most variable ITS regions, where C. xyli subsp. cynodontis and other closely related Clavibacter species had either deletions or nonhomologous sequences. These two primers primed the amplification of the expected 438-bp DNA product only from the $21 C$. xyli subsp. xyli strains, including a worldwide collection of 19 strains and two locally isolated strains. The PCR protocol also can be used to differentiate $C$. xyli subsp. xyli from $C$. xyli subsp. cynodontis, a task that was not possible using serological, biochemical, and DNA hybridization methods (13,14; unpublished). The $89.9 \%$ sequence identity between the two L1/G1-primed PCR products from these two subspecies may account for the fact that the 566-bp L1/G1primed PCR product from $C$. xyli subsp. xyli hybridized to the 546-bp PCR product from $C$. xyli subsp. cynodontis (unpublished).

Unlike previous reports $(3,15,17,29)$, we found that PCR could be performed directly on $C$. xyli subsp. xyli cells from culture and from $C$. xyli subsp. xyli-infected sugarcane vascular sap, although a PVPand ficoll-containing reaction mixture was used when dealing with sap sample (unpublished). A limiting factor in applying the PCR protocol to detect C. xyli subsp. xyli from sugarcane vascular sap is PCR inhibitors $(25,29,30,34)$. Various reagents have been added to nucleic acid extraction buffer or PCR reaction buffer by different researchers to circumvent the inhibition problem, including PVP (31), polyethylene glycol (PEG) (31), blotto (10\% skim milk) (29), BSA (32), and $\mathrm{H}_{2} \mathrm{O}_{2}$ (1). Diluting (30) or washing (34) field samples before PCR assay may also reduce inhibitors' effects. In this study, inclusion of $0.8 \%(\mathrm{wt} / \mathrm{vol})$ PVP $(\mathrm{MW}=360,000)$ and $0.8 \%(\mathrm{wt} / \mathrm{vol})$ of ficoll $(\mathrm{MW}=$ $400,000)$ in reaction buffer, which are used regularly in DNA hybridization studies, improved the efficiency of PCR assay on vascular sap samples (unpublished). We do not know the exact mechanism, but these high-molecular-weight polymeric matrices may irreversibly adsorb inhibitor compounds (31). However, we feel that even with the addition of these compounds in the reaction buffer, the presence of inhibitors in sugarcane vascular sap may still affect the efficiency of PCR detection. This could be one reason why $C$. xyli subsp. xyli was not detected in the seven sap samples tested positive by TB-IBA but not by PCR. The development of a highly specific PCR protocol offers some distinct advantages over other diagnostic methods. Sap samples are more easily transported than stalk tissue samples and can be stored for longer periods of time before processing. The PCR protocol can also have other applications where tissue blots may be inadequate, e.g., other sugarcane tissues, other host plants, soil samples. Experiments are currently being conducted to increase the level of sensitivity of PCR performed directly on sap samples.

In conclusion, a PCR protocol was developed that specifically amplified a 438bp DNA product from the ITS region of 16S-23S rDNA from $C$. xyli subsp. xyli, the causal agent of the sugarcane ratoon stunting disease $(12,22,38)$. In addition, the efficiency of PCR detection in sugarcane vascular sap was improved by the inclusion of PVP and ficoll, two high-molecularweight polymeric matrices, into the PCR reaction buffer. The PCR protocol can be immediately applicable in many sugarcane diagnostic laboratories to help detect and control one of the most serious sugarcane diseases.

\section{ACKNOWLEDGMENT}

We thank Steve M. Brumbly (Bureau of Sugar Experiment Stations, Australia) for providing us with a diverse collection of 19 C. xyli subsp. xyli strains, Xiang Li (Terragene, Vancouver, Canada) for genomic DNA of five strains of C. michiganensis and two strains of Rathayibacter, Mary Metzler (University of Turku, Turku, Finland) for genomic DNA of C. xyli subsp. cynodontis strain $C x c 7$, Chris A. Clark (Louisiana State University, Baton Rouge) for various $X$. albilineans and other Xanthomonad strains, Jeffrey W. Cary, Ken C. Ehrlich, and Barbara A. Triplett (USDA, ARS, Southern Regional Research Center, New Orleans, LA) for DNA sequence analysis, and Kathryn Z. Warnke for technical assistance. This research was partially supported by a competitive grant from the American Sugar Cane League of the U.S.A., Inc., Thibodaux, LA.

\section{LITERATURE CITED}

1. Akane, A. 1996. Hydrogen peroxide decomposes the heme compound in forensic specimens and improves the efficiency of PCR. BioTechniques 21:392-394.

2. Altschul, S. F., Gish, W., Miller, W., Myers, E. W., and Lipman, D. J. 1990. Basic local alignment tool. J. Mol. Biol. 215:403-410.

3. Astua-Monge, G., Stall, R. E., and Davis, M. J. 1995. Diagnosis of ratoon stunting disease of sugarcane by PCR-based procedures. Sugar Azucar 90(6):37.

4. Bailey, R. A. 1977. The systemic distribution and relative occurrence of bacteria in sugarcane varieties affected by ratoon stunting disease. Proc. S. Afr. Sugar Technol. Assoc. Annu. Congr. 51:55-56.

5. Barry, T., Colleran, G., Glennon, M., Dunican, L. K., and Gannon, F. 1991. The 16/23S ribosomal spacer region as a target for DNA probes to identify eubacteria. PCR Methods Applications 1:51-56.

6. Benda, G. T. A., and Ricaud, C. 1977. The use of heat treatment for disease control. Proc. Int. Soc. Sugar Cane Technol. 16:483-496.

7. Chung, C. H., Lin, C. P., and Chen, C. T. 1994. Development and application of cloned DNA probes for Clavibacter xyli subsp. xyli, the causal agent of sugarcane ratoon stunting. J. Phytopathol. 141:293-301.

8. Comstock, J. C., and Irey, M. S. 1992. Detection of the sugarcane leaf scald pathogen Xanthomonas albilineans, using tissue blot immunoassay, ELISA, and isolation techniques. Plant Dis. 76:1033-1035.

9. Croft, B. J., Greet, A. D., Leaman, T. M., and Teakle, D. S. 1994. RSD diagnosis and varietal resistance screening in sugarcane using the EB-EIA technique. Proc. Aust. Soc. Sugar Cane Technol. 16:143-151.

10. Damann, K. E., Jr. 1988. Alkaline-induced metaxylem autofluorescence: A diagnostic symptom of ratoon stunting disease of sugarcane. Phytopathology 78:233-236.

11. Davis, M. J. 1985. Direct-count techniques for enumerating Clavibacter xyli subsp. xyli which cause ratoon stunting disease of sugarcane. Phytopathology 75:1226-1231.

12. Davis, M. J., Gillaspie, A. G., Jr., Harris, R. W., and Lawson, R. H. 1980. Ratoon stunting disease of sugarcane: Isolation of the causal bacterium. Science 210:1365-1367.

13. Davis, M. J., Gillaspie, A. G., Jr., Vidaver, A. K., and Harris, R. W. 1984. Clavibacter: A new genus containing some phytopathogenic coryneform bacteria, including Clavibacter xyli subsp. xyli sp. nov., subsp. nov. and Clavibacter xyli subsp. cynodontis subsp. nov., pathogens that cause ratoon stunting disease of sugarcane and Bermudagrass stunting disease. Int. J. Syst. Bacteriol. 34:107-117.

14. Davis, M. J., Lawson, R. H., Gillaspie, A. G., Jr., and Harris, R. W. 1983. Properties and relationships of two xylem-limited bacteria and a mycoplasmalike organism infecting Bermuda grass. Phytopathology 73:341-346.

15. Dreier, J., Bermpohl, A., and Eichenlaub, R. 1995. Southern hybridization and PCR for specific detection of phytopathogenic Clavibacter michiganensis subsp. michiganensis. Phytopathology 85:462-468.

16. Drennan, J. L., Westra, A. A. G., Slack, S. A., Delserone, L. M., Collmer, A., Gudmestad, N. C., and Oleson, A. E. 1993. Comparison of a DNA hybridization probe and ELISA for the detection of Clavibacter michiganensis subsp. sepedonicus in field-grown potatoes. Plant Dis. 77:1243-1247.

17. Fegan, M., Smith, G. R., Roberts, S. E, Van de Velde, R., Teakle, D. S., and Hayward, A. C. 1994. Detection of Clavibacter xyli subsp. $x y l i$ in ratoon stunting disease: A DNA-based approach. Page 51 in: Proc. Intl. Soc. Sugar Cane Technol. Pathology Workshop, Brisbane, Australia, 4th.

18. Firrao, G., and Locci, R. 1994. Identification of Clavibacter michiganensis subsp. sepedonicus using polymerase chain reaction. Can. J. Microbiol. 40:148-151. 
19. Gannon, F. 1994. DNA probes for the identification of microorganisms. Industrial Microbiol. 15:71-76.

20. Gillaspie, A. G., Jr. 1978. Ratoon stunting disease of sugarcane: Serology. Phytopathology 68:529-532.

21. Gillaspie, A. G., Jr., Flax, G., and Koike, H. 1976. Relationship between numbers of diagnostic bacteria and injury by ratoon stunting disease in sugarcane. Plant Dis. Rep. 60:573575.

22. Gillaspie, A. G., Jr., and Teakle, D. S. 1989. Ratoon stunting disease. Pages 59-80 in: Diseases of Sugarcane. C. Ricaud, B. T. Egan, A. G. Gillaspie, Jr., and C. G. Hughes, eds. Elsevier Publishing, Amsterdam.

23. Harris, R. W., and Gillaspie, A. G., Jr. 1978. Immunofluorescent diagnosis of ratoon stunting disease. Plant Dis. Rep. 62:193-196.

24. Harrison, N. A., and Davis, M. J. 1988. Colonization of vascular tissues by Clavibacter $x y l i$ subsp. xyli in stalks of sugarcane cultivars differing in susceptibility to ratoon stunting disease. Phytopathology 78:722-727.

25. Henson, J. M., and French, R. 1993. The polymerase chain reaction and plant disease diagnosis. Annu. Rev. Phytopathol. 31:81109.

26. Honeycutt, R. J., Sobral, B. W. S., and McClelland, M. 1995. tRNA intergenic spacers reveal polymorphisms diagnostic of Xanthomonas albilineans. Microbiology 141:32293239.
27. Jensen, M. A., Webster, J. A., and Straus, N. 1993. Rapid identification of bacteria on the basis of polymerase chain reaction-amplified ribosomal DNA spacer polymorphisms. Appl. Environ. Microbiol. 59:945-952.

28. Koike, H., Gillaspie, A. G., Jr., and Benda, G. T. A. 1982. Cane yield response to ratoon stunting disease. Int. Sugar J. 84:131-133.

29. Li, X., and De Boer, S. H. 1995. Selection of polymerase chain reaction primers from an RNA intergenic spacer region for specific detection of Clavibacter michiganensis subsp. sepedonicus. Phytopathology 85:837-842.

30. Lopes, S. A., and Damann, K. E. 1993. PCR amplification of DNA from bacterial pathogens of sugarcane. (Abstr.) Phytopathology 83:1398.

31. MacKenzie, D. J., McLean, M. A., Mukerji, S., and Green, M. 1997. Improved RNA extraction from woody plants for the detection of viral pathogens by reverse transcriptionpolymerase chain reaction. Plant Dis. 81:222226.

32. McGregor, D. P., Forster, S., Steven, J., Adair, J., Leary, S. E. C., Leslie, D. L., Harris, W. J., and Titball, R. W. 1996. Simultaneous detection of microorganisms in soil suspension based on PCR amplification of bacterial 16S rRNA fragments. BioTechniques 21:463-471.

33. Metzler, M. C., Zhang, Y.-P., and Chen, T.-A. 1992. Transformation of the Gram-positive bacterium Clavibacter xyli subsp. cynodontis by electroporation with plasmids from the
IncP incompatibility group. J. Bacteriol. 174:4500-4503.

34. Pan, Y.-B., Grisham, M. P., and Burner, D. M 1997. A polymerase chain reaction protocol for the detection of Xanthomonas albilineans, the causal agent of sugarcane leaf scald disease. Plant Dis. 81:189-194.

35. Rademaker, J. L. W., and Janse, J. D. 1994 Detection and identification of Clavibacter michiganensis subsp. sepedonicus and Clavibacter michiganensis subsp. michiganensis by nonradioactive hybridization, polymerase chain reaction, and restriction enzyme analysis. Can. J. Microbiol. 40:1007-1018.

36. Sambrook, J., Fritsch, E. F., and Maniatis, T. A. 1989. Molecular Cloning: A Laboratory Manual. 2nd ed. Cold Spring Harbor Laboratory, Cold Spring Harbor, NY

37. Slack, S. A., Drennan, J. L., Westra, A. A. G. Gudmestad, N. C., and Oleson, A. E. 1996. Comparison of PCR, ELISA, and DNA hybridization for the detection of Clavibacter michiganensis subsp. sepedonicus in fieldgrown potatoes. Plant Dis. 80:519-524.

38. Steindl, D. R. L. 1961. Ratoon stunting disease. Pages 433-459 in: J. P. Martin, E. V. Abbort, and C. G. Hughes, eds. Sugarcane Disease of the World, Vol. 1. Elsevier Publishing, Amsterdam.

39. Steindl, D. R. L. 1976. The use of phase contrast microscopy in the identification of ratoon stunting disease. Proc. Qld. Soc. Sugar Cane Technol. 43:71-72. 